\title{
A rare case of Munchausen syndrome: foreign body ingestion
}

\author{
Nadir bir munchausen sendromu olgusu: yabancı cisim yutulması
}

Emin Uysal ${ }^{*}$, Hatice Karaçam ${ }^{1}$, Serap Aydemir Dikici ${ }^{1}$

1.Department of Emergency Medicine, University of Health Sciences, Bagcilar Training and Research Hospital, Istanbul, Turkey.

\begin{abstract}
Munchausen Syndrome (MS) is characterized by mental or physical diseases intentionally induced by the patients. In this case report, we aimed to present MS and review current literature. A 36-year-old female patient was admitted to the emergency room with the complaint of abdominal pain that developed after swallowing stitch needles. Physical examination revealed minimal tenderness in the abdomen with palpation. The plain abdominal X-ray revealed more than ten needle-shaped opacities. During the anamnesis, the patient was incoherent and too determined to have a surgical intervention, which gave rise to a suspicion of MS. A psychiatrist consultation was conducted, she was diagnosed with MS and hospitalization of the patient was planned. Clinical suspicion and detailed anamnesis are the key for the diagnosis. Physicians should bring to mind the diagnosis of MS and seek psychiatric support in patients with frequent hospital admissions, incompatibility between their complaints and a history and examination findings.
\end{abstract}

Keywords: Munchausen syndrome, foreign bodies, diagnosis

\section{ÖZ}

Munchausen Sendromu (MS), hastalar tarafından kasıttı olarak üretilen zihinse veya fiziksel hastalıklarla karakterizedir. Bu olgu sunumunda MS'i sunmayı ve güncel literatürü gözden geçirmeyi amaçladık. 36 yaşındaki kadın hasta, dikiş iğneleri yutma sonrası gelişen karın ağrısı şikâyetiyle acil servise başvurdu. Fizik muayenede palpasyonla batında minimal hassasiyet vardı. Cekilen ayakta direkt batın grafisinde ondan fazla iğne şeklinde opasite mevcuttu. Hastanın anamnezinde tutarsızlıklar ve cerrahi girişim için aşırı istekli olması MS şüphesini uyandırdı. Psikiyatri konsültasyonu istendi, MS tanısıyla yatışı planlandı. Klinik şüphe ve ayrıntıı anamnez, tanı için anahtardır. Hekimler, hastaneye sık başvuran, şikâyetleri ile öykü ve muayene bulguları arasında uyumsuzluk olan hastalarda MS tanısını akla getirmeli ve psikiyatrik destek almalıdır.

Anahtar Kelimeler: Munchausen sendromu, yabancı cisim, tanı

Received: 09.02.2021 Accepted: 06.03.2021 Published (Online): 30.08.2021

*Corresponding Author: Emin Uysal. Department of Emergency Medicine, University of Health Sciences,

Bagcilar Training and Research Hospital, Istanbul, Turkey, +905305431937, dreminuysal@hotmail.com

ORCID: 0000-0003-3905-0753

To cited: Uysal E, Karaçam H, Aydemir Dikici S. A rare case of Munchausen syndrome: foreign body ingestion. Acta Med. Alanya 2021;5(2): 195-197 doi:10.30565/medalanya.877190 


\section{INTRODUCTION}

M unchausen Syndrome (MS) was first defined by Asher in 1951, for a group of persons who presented to various hospitals with fabricated medical history and were allowing unnecessary surgical interventions to be performed on them. This syndrome is named after Karl Friedrich von Munchausen (1720-1797), known for his exaggerated war hero stories who worked as mercenaries in the Russian Army. The main feature of the syndrome is the deliberate production of physical or psychiatric symptoms related to almost any system [1]. Patients with a wide range of signs and symptoms apply to the emergency departments as well as other clinics with the hope of hospitalization and surgery. In this case report we present a patient with the complaint of abdominal pain who was ultimately diagnosed with MS.

\section{CASE REPORT}

A 36-year-old female patient was admitted to the emergency room with the complaint of abdominal pain developing after allegedly swallowing stitch needles. No history of drug use was reported and her medical history revealed abdominal surgery using stitch needles had been performed. Vital signs findings were normal and after physical examination, a number of old scars and freshly injured wounds were observed on the abdominal skin, though no abdominal guarding and rebound tenderness was induced. Radiopaque foreign bodies compatible with a large number of stitch needles within the abdomen, as well as staple stitching in two different areas on the left side of the abdominal skin were observed on the plain abdominal X-ray (Figure 1). The patient reported accidentally swallowing stitching needles and after an investigation of her earlier medical reports, we found multiple earlier presentations, with complaints such as skin incision, foreign body ingestion and skin cut wounds. During the anamnesis, the patient was incoherent and very determined to undergo a surgical intervention, which gave rise to a suspicion of MS. The psychiatrist's consultation resulted in a decision to admit, however she refused to be admitted and left the hospital against medical advice.

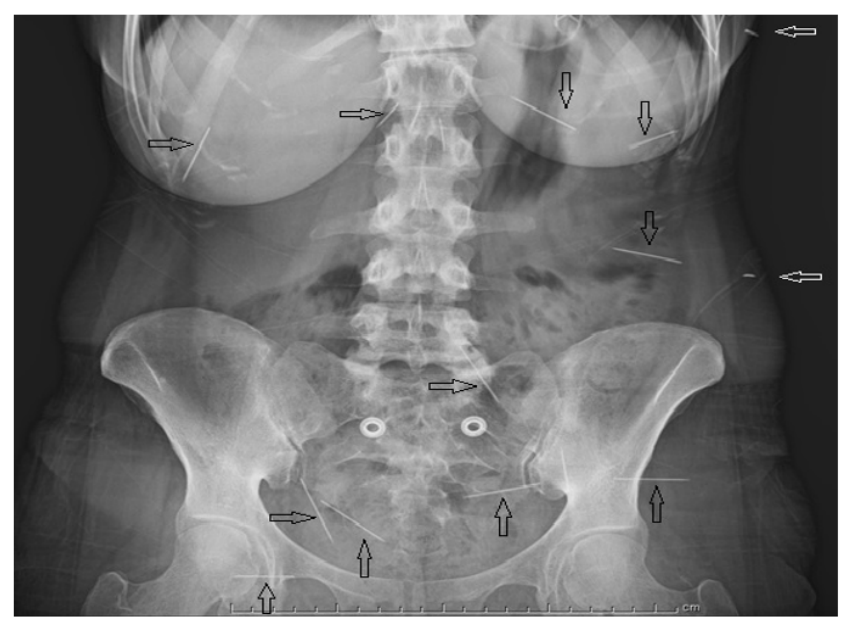

Figure 1. On the plain abdominal $\mathrm{X}$-ray radio-opaque foreign bodies (black arrow) and metallic stitches (white arrow) on the left side of the abdomen is shown.

\section{DISCUSSION}

Patients with MS have a long-term medical history of a wide range of medical and surgical applications in different hospitals, imitating the symptoms of actual diseases. The presence of psychiatric diseases in the family increases the risk for this syndrome [2]. The disease usually occurs in early adult life and mostly in males of low socioeconomic status. Childhood history usually reveals neglect, abandonment and harmful behavior by a parent. Hospital staff and doctors are perceived as a "tool of interest and love" by these patients. Those with complaints that are incompatible with the physical examination should be carefully evaluated. Patients with dramatic, aggressive, attention-grabbing behavior, atypical symptoms, consulting a large number of doctors, being themselves a health-care personnel and using literary language, are relevant behaviors for the diagnosis [3]. The inconsistency in the present medical history, medical records showing up to 100 applications on different occasions and the persistence of the same complaints, lead us to a diagnosis in this case. The patient had a number of old scars as well as newly sutured wounds. Typical MS patients apply to emergency departments and other clinics with complaints of non-healing wounds, recurrent infections, foreign bodies, necrotizing fasciitis; patients will allow many invasive procedures for diagnosis and treatment. It has been reported that the syndrome could coexist with borderline personality disorder [4]. One patient inserted a needle into her urethra for 
4 days, to the point that she could not remove it by herself and applied to the emergency department with abdominal pain; the needle was removed by surgery in the abdomen [5]. Our patient also had a surgery after swallowing a sewing needle and had applied to another hospital two years prior, with complaints of abdominal pain.

MS should be distinguished from other medical and psychiatric diseases. In somatoform diseases such as somatization disorder and conversion, symptoms appear completely unconsciously and involuntarily: the patients believe they are ill and there is no simulation. In malingering (lying), the patient deliberately mimics the symptoms of the disease for secondary gains, such as money or for protection. MS is situated midway of these two conditions in this spectrum. Symptoms appear consciously with subconscious impulses [6]. Patients with MS are not mindful of any purpose and don't seek to gain any profit [7].

The pathophysiology of the disease is uncertain, as in the case of many psychiatric diseases, and its prognosis is quite poor. In addition, the constant changing of physicians or hospitals makes it difficult to follow up on those patients [4]. A multidisciplinary approach, especially psychiatric evaluation, plays an important role in the management of the MS [8]. In the treatment of the disease, psychotherapy, family therapy and behavioral therapy are recommended, along with pharmacotherapy.

\section{CONCLUSION}

The most important and first step in the diagnosis of MS is to consider the prospect of the existence of the disease in our patients. Early diagnosis reduces unnecessary, repeated health costs and the risk of self-harm.

Conflict of Interest: The author has no conflict of interest related to this article.

Funding sources: The author declared that this study has received no financial support

Peer-review: Externally and internally peer reviewed.

\section{REFERENCES}

. Turner J, Reid S. Munchausen's syndrome. Lancet. 2002;359;(9303):346-9. PMID: 11830219

2. Lin JL, Servat JJ, Bernardino CR, Goldberg RA, Levin F. Bilateral korneal perforations and autoproptosis as self-induced manifestations of ocular munchausen's syndrome. Orbit. 2012;31(4):252-5. PMID: 22571651

3. Keleș S, Öndaş O, Dursun OB, Pınar CL, Ateş O. Ocular Munchausen Syndrome; Self Introduction of Clay and Glass Parts to Conjunctival Fornix. J Clin Anal Med. 2014;5(2):209-11. DOI: 10.4328/jcam.3124

4. Lazzeri D, Romeo G, De Rossa M, Iannotti G, Colizzi L, Stabile M, et al. Plastic surgery and Munchausen's syndrome 'surgeon beware!. J Plast Reconstr Aesthet Surg. 2010;63(3):319-20. PMID: 19604739

5. Lauwers R, Winkel NVD, Vanderbruggen N, Hubloue I. Munchausen syndrome in the emergency department mostly difficult, sometimes easy to diagnose: a case report and review of the literature. World J Emerg Surg. 2009;4-38. PMID: 19909508

6. Livaoglu M, Kerimoglu S, Hocaoglu C, Arvas L, Karacal N. Munchausen's syndrome: a rare self-mutilation syndrome. Dermatol Surg. 2008;34(9):1288-91. PMID: 18616542

7. Gözlükaya A. A Case of Munchausen Syndrome Admitting With Hemorrhage. Akademik Acil Tıp Olgu Sunumları Dergisi. 2010;1(1):47-9.

8. Demiralp CÖ, Akkaya H, Duman Y, Akşam B, Demirseren ME. A Rare Case Presenting With Complaints Of Foreign Body On Scalp: Munchausen Syndrome. Ankara Medical Journal. 2012;12(2):106-8.

\begin{tabular}{|l|l|}
\hline Author/ORCID & Authorship Contrubition \\
\hline $\begin{array}{l}\text { Emin Uysal } \\
\text { 0000-0003-3905-0753 }\end{array}$ & $\begin{array}{l}\text { Consept, Design, Materials, Data Collection, } \\
\text { Interpretation, Literature Search, Manuscript } \\
\text { Writing, Final Approval, Critical Review. }\end{array}$ \\
\hline $\begin{array}{l}\text { Hatice Karaçam } \\
\text { 0000-0001-5207-3074 }\end{array}$ & $\begin{array}{l}\text { Materials, Data Collection, Interpretation, } \\
\text { Literature Search, Final Approval, Critical } \\
\text { Review. }\end{array}$ \\
\hline $\begin{array}{l}\text { Serap Aydemir Dikici } \\
\text { 0000-0002-5163-0286 }\end{array}$ & $\begin{array}{l}\text { Materials, Data Collection, Interpretation, } \\
\text { Literature Search, Final Approval, Critical } \\
\text { Review. }\end{array}$ \\
\hline
\end{tabular}

